\title{
The Differences of Academic College Student's Achievement Between Literation Field Class from High School and Man Students on English Education at Faculty of Tarbiyah and Teachers Training of State Islamic University of North Sumatra
}

\author{
Ernita Daulay ${ }^{1}$, Tien Rafida ${ }^{2}$ \\ Lectures at PBI FITK State Islamic University of North Sumatera, Medan, Indonesia \\ titinrafida@gmail.com
}

\begin{abstract}
This research describes the context of learning or lectures at academic achievement colleges known as achievement indexes (IP) and cumulative grade index (GPA). This is confirmed in the process standard operation (SOP) of Lectures and Curriculum with the number Un-11.JSOPP-04-02.R0 published by the North Sumatra State Islamic University Medan that Academic achievement is the result achieved by student guidance in study activities at the University North Sumatra State Islamic Medan as proof of the success that has been achieved after conducting learning or lecture activities. The results achieved by these students can take the form of subject values, Grade Point Average (GPA), championship rank, graduation grade, and completing studies on time. In the perspective of the study of academic achievement theory known as learning outcomes. The discussion of learning outcomes cannot be separated from the study of the concept of learning itself, because learning outcomes are obtained after going through the learning process carried out by students. This research carried out using a mixed method approach, which is a combination of qualitative and quantitative research. Qualitative research used is naturalistic, because it is based on the consideration that what is sought in this research is data that will describe and paint complex social reality in such a way that it becomes a concrete social phenomenon. The research situation chosen in this study was the academic achievement of students from high school and aliyah madrasa in the English Education Study Program at the Faculty of Tarbiyah and Teacher Training at North Sumatra State Islamic University Medan, covering a broad context, involving many actors, time different places, different processes and processes.
\end{abstract}

Keywords: academic achievement; lecture activities; learning outcomes; influence learning factors

\section{Introduction}

The progress of national education must be able to guarantee equal opportunities for education, quality improvement and management of education to face challenges in accordance with the demands of change in the global era. Indonesia is incorporated in the AFTA agreement (ASEAN Free Trade Area). This agreement makes the real and non-real sectors easy and open among ASEAN countries. Higher education is one of the important aspects in nation building. Higher education as an institution that organizes higher education is responsible for providing provision to students with the knowledge and expertise needed to answer the challenges ahead. Higher education also produces science through research and acts as an intermediary for the transfer, adaptation and dissemination of knowledge found elsewhere, and supports the government and business world with its advice and consultancy services. Higher education also plays an important role in the social field by realizing national identity and offering a forum for pluralistic debates which can be accounted for by 
scholarship.

Tilaar (2003) explains that the national education system as an organization must be dynamic, flexible so that it can absorb the changes that occur quickly, among others due to the development of science and technology, changes in society towards an increasingly democratic society and respect for human rights. all higher education resources become superior universities. Higher education is required to pay more attention to the needs of students and their teaching staff as customers and stakeholders. Decentralization of education offers a new paradigm for university managers to be more independent and develop all their resources and potential. These demands are expected to have implications for the preparation of curriculum and university management. The change in management of education has become a necessity, so that universities are required to make management changes so that the alumni are truly qualified as the realization of high accountability.

\subsection{The Background of the Study}

The 2013 Human Development Report shows that Indonesia's HDI increased from 0.617 (position 124 from 187 countries) in 2011 to 0.684 in 2013 and placed Indonesia ranked 108 out of 187 countries (UNDP, 2014). Likewise with the Global Competitiveness Index (GCI) issued by the World Economic Forum (WEF), Indonesia's competitiveness has increased from rank 50 in 2012-2013 to rank 38th out of 148 countries in 2013-2014 (Schwab, 2013) . The report means that the factors of education, health, and the economy play a major role in driving the growth rate of Indonesia's HDI. The increase in competitiveness refers to three main indicators, namely: (1) basic requirements covering basic health and education, (2) increasing life expectancy and improving the quality of education, and (3) innovation in the quality and quantity of education, driven by the program rehabilitation of school physical facilities, distribution of BOS funds, and improving the quality of lecturers and teachers (Mardhiyah, 2012). Decentralization of education offers a new paradigm for university managers to be more independent and develop all their resources and potential. These demands are expected to have implications for the preparation of curriculum and university management. The change in management of education has become a necessity, so that universities are required to make management changes so that the alumni are truly qualified as the realization of high accountability.

Responding to the above, the North Sumatra Islamic University of Medan is an institution of higher education characterized by Islam which was founded in 1973. At present the development of Medan North Sumatra Islamic University is accelerating along with the progress of the era, namely by opening S.2 and S. programs. 3. Thousands of scholars have been produced by the North Sumatra State Islamic University in Medan and they are active in the midst of people who are teachers, bureaucrats, politicians, clerics, religious and other professional judges who are in the midst of the community who develop their knowledge. .

This shows the existence of the North Sumatra State Islamic University in Medan in general and the study program of English Language Education at the Faculty of Science Tarbiyah and Teacher Training of the North Sumatra State Islamic University Medan specifically in the community has indeed been admittedly acceptable. Therefore, to improve its existence, the study program of English Language Education at the Faculty of Tarbiyah and Teacher Training at the State University of North Sumatra Medan continues to improve itself in responding to the increasingly complex needs and challenges. Improvement is carried out, among others, by adding teaching staff, modernizing management and completing the 
facilities needed in conducting lectures. One indicator of the success of a university is the study program of English Language Education Faculty of Tarbiyah and Teacher Training, North Sumatra Islamic University Medan, which is a student's learning achievement which is very much influenced by the input of new students who have different educational backgrounds (from school). The initial ability factor (prior knowledge) possessed by students during their education at the secondary school level can influence their learning achievement in college. Hailikari, Katajavuori, \& Lindblom-Ylanne (2008) states "prior knowledge has been considered the most important factor influencing learning and student achievement". As we know, humans when working on things, both thinking and working physically, always use various kinds of memory stored in their brains (residuals) in the form of knowledge (knowledge) (expertise), and experience (experience). These elements are very influential on the type of interaction that takes place naturally (Hansberger in Harsono, 2010: 1). The prior knowledge that we have before will probably be recalled and become the prerequisite ability for the next knowledge. Where at the college level learning is emphasized in high-order thinking skills that include the ability to think critically and creatively.

\subsection{The Problem of Formulation}

The formulation of the problem in this study is as follows:

1. What is the student's response to the study program of English Language Education at the Faculty of Tarbiyah and Teacher Training in North Sumatra, Medan?

2. What are the expectations for the study program in the English Language Education Faculty of Tarbiyah and Teacher Training in North Sumatra, Medan?

3. Are there differences in students academic achievement from high school and Aliyah Madrasa?

4. What are the efforts to improve the quality and academic performance of the North Sumatra Medan Faculty of Tarbiyah and Teacher Training in Medan?

\subsection{The Purpose of the Study}

The purpose of this study is to find out:

1. The response of students to the study program of English Language Education at the Faculty of Tarbiyah and Teacher Training at the State Islamic University of North Sumatra, Medan

2. Students' expectations of the English Language Education study program at the Faculty of Tarbiyah and Teacher Training at the State Islamic University of North Sumatra, Medan.

3. Differences in student academic achievement from high school and Aliyah Madrasah.

4. Efforts to improve the quality and academic performance of the English Language Education program at the Faculty of Tarbiyah and Teacher Training at the State Islamic University of North Sumatra, Medan.

\subsection{The Objectives of the Study}

This research is expected to be useful for:

1. The manager of the English Language Education program at the Faculty of Tarbiyah and Teachers Training at the North Sumatra State Islamic University in Medan as a frame of reference in developing study programs.

2. Other researchers as information material and models for further research. 


\section{Theoritical Review}

\subsection{Academic Student's Achievement}

Referring to the Large Indonesian Language Dictionary (2007), it is obtained an illustration that achievement is the result that has been achieved (from what has been done, done, etc.). Based on this understanding, the nature of achievement is final, because all efforts have been made and produced a form of appreciation. Syah (2001) explains that achievement is a change in all psychological domains as a result of students' experiences and learning processes. This statement means that the biggest cause of achievement is the ongoing learning done both in the school environment, family environment, and social or community environment. In the context of learning or lectures in higher education academic achievement is known as the achievement index (IP) and cumulative grade index (GPA). This is confirmed in the process standard operation (SOP) of Lectures and Curriculum with the number Un-11.JSOPP-04-02.R0 published by the North Sumatra State Islamic University Medan that Academic achievement is the result achieved by student guidance in study activities at the University North Sumatra State Islamic Medan as proof of the success that has been achieved after conducting learning or lecture activities. The results achieved by these students can take the form of subject values, Grade Point Average (GPA), championship rank, graduation grade, and completing studies on time.

In the perspective of the study of academic achievement theory known as learning outcomes. The discussion of learning outcomes cannot be separated from the study of the concept of learning itself, because learning outcomes are obtained after going through the learning process carried out by students. Siregar and Nara (2010) cite Burton's opinion explaining that learning is a process of changing behavior in individuals because there is interaction between individuals and individuals and individuals with their environment so that they are better able to interact with their environment.

\subsection{The Factors of Affecting Learning}

The factors that influence learning will certainly have implications for learning outcomes obtained by students. This is explained by Siregar and Nara (2010) that there are two main factors that influence learning outcomes, namely:

\section{A. Internal factors include:}

1) Physiological factors consist of the condition of the body, the state of certain physiological functions.

2) Psychological factors include talent, interest, intelligence and motivation.

\section{B. External factors are:}

1) Social factors include the family environment, namely parents, home atmosphere, family economic capacity, cultural background, teacher environment, namely teacher and student interaction, relationships between students, ways of presenting learning materials, and community environment, namely environmental patterns of life, activities in society and mass media.

2) Non-social factors include school facilities and infrastructure, namely curriculum, educational media, building conditions, learning facilities, study time, home and nature. An understanding of learning achievement is divided into two types, namely academic and non-academic. Academic achievement is the result of measuring learning based on cognitive and affective values. Assessment in the 
cognitive domain is based on mastery of concepts, principles and theories. This can be seen from the results of daily test scores (UH), midterm tests (UTS) and end of semester tests (UAS), or can be seen from academic competitions such as science and olympic competitions. In contrast to cognitive / knowledge that results can be immediately known, attitude assessment is rather difficult to do. But it can be obtained through instruments such as attitude scale, observation, interviews, and so forth. Academic achievement involves many components such as teaching staff, availability of library materials, and the formation of school culture. Non-academic achievements are the learning outcomes of skills. The discovery of this achievement is measured by the level of quality of hard work and perseverance. Extracurricular activities as a place to explore the talents and interests of students in developing non-academic achievements. Both academic and non academic achievements, the level of effectiveness of learning can be known by educators by using a certain standard or measure to be achieved at a certain time. Measurements can be through tests or non-tests tailored to the form given during the learning process.

Anni (2004) explains the factors that influence learning achievement are divided into2, namely internal factors and external factors. Here's the explanation:

a. Internal factors, which include physical aspects, such as health of body organs, psychological aspects, such as intellectual, emotional, motivational, and social aspects, such as the ability to socialize with the environment.

b. External factors, for example variations and the degree of difficulty of the material being studied, place of study, climate, environmental atmosphere, culture of learning society and others.

Furthermore Nurdin (2005) explains several factors that can influence student learning achievement, among others:

a. Internal factors, namely factors that originate in the individual include: (a). physiological or physical conditions. (b) psychological conditions, this includes the talents, interests, motivations, attitudes, intellectuals of students.

b. External factors, namely factors that originate from outside the individual include:

(a) Social environment, namely friends, teachers, family, community.

(b).Physical environment, namely schools, facilities, housing: houses, dormitories, boarding houses.

The same thing as the explanation above Shah (2009) explains the factors that influence academic achievement are:

a. Internal factors, namely the condition or physical and spiritual condition of students.

b. External factors, namely environmental conditions around students.

The environment around students is divided into three parts including:

\section{1) Family Environment.}

Family has a very important role in developing a child's personality. Care for loving parents, and education about the values of life, both religious and socio-cultural given are conducive factors to prepare children to be healthy individuals and members of society. The family environment is part of the lives of students. In the environment the 
students live and interact in the chain of life called the ecosystem. Interdependence between biotic and abiotic environments cannot be avoided. During the life of students can not avoid natural environment and socio-cultural environment. The interaction of these two different environments always occurs in filling students' learning lives. Both have a significant influence on students' learning in school.

Family's circle is the environment where students live, live and try in it. Environmental pollution is a disaster for students who live in it. The state of temperature and humidity affects the learning of students at school. Learning in fresh air will be better than learning in hot, stuffy air.

\section{2) School Environment}

Schools are formal educational institutions that systematically carry out guidance, teaching and training programs in helping students to be able to develop their potential, both concerning moral, spiritual, intellectual, emotional or social aspects. Regarding the role of schools in developing children's personalities. School is a determining factor for the development of personality (children) students, both in ways of thinking, behaving and behaving. School acts as family substitution, with substitution of parents. There are several reasons why schools play a meaningful role for the development of a child's personality, namely:

1) students must be present at school.

2) the school gives influence to children early, along with the development period of "self-concept".

3) students spend more time in school than in other places outside the home.

4) schools provide opportunities for students to succeed.

5) the school provides the first opportunity for children to assess themselves, and their abilities realistically.

\section{3) Community Environment}

The community environment is a social environment, because in general children socialize with their peers. This environment has a role that is quite important for the development of his personality. The main factors that determine interpersonal attraction between children are similarities in interests, values, opinions, and personality traits. As members of society, students cannot escape social ties. The formed social system binds students' behavior to submit to social norms, morality, and applicable laws in society.

The same is true at school. Regulations and rules must be followed by students. Violations committed by students will be penalized according to the type and severity of the violation. The birth of school regulations aims to regulate and shape the behavior of students who support the success of learning in school. The social environment that affects learning activities is the parents and families of the students themselves, parental characteristics, family management practices, family tension, and family demographics (home location), all of which can have good or bad effects on learning activities and outcomes achieved by students.

\subsection{Theoretical Framework}

The assessment of student academic achievement based on background is not enough to see only the high school label or the Islamic secondary school. The difference between 
high school and Islamic schools is not only in definition, organizational structure and educational goals, but also in other aspects that are closely related to the curriculum which includes educational orientation, focus on the curriculum, sensitivity to community development and others. The substance that distinguishes between high school and aliyah madrasas is reflected in the dimensions of the curriculum so that in comparing academic achievement between students with a high school education background and philosophically at least the madrasah aliyah must be seen the number of hours of lessons and lessons from supporting subjects the formation of thought patterns that lead to the ability to follow learning activities.

On the other hand, academic achievements obtained by students are formed from the accumulation of knowledge, attitudes and skills in carrying out learning activities. The higher the knowledge, the more positive the attitude and the more real the skills, the higher the learning outcomes obtained by students. No less important is the difference between students' academic achievement is the level of entry behavior (initial knowledge) of students who are different from one another. Related to this, the students' initial knowledge is related to the knowledge gained during the learning process at the high school level with the Islamic school which is of course different in its implementation. The learning activities received so far have contributed to the ability of students to achieve their academic achievements in higher education, particularly in this case in the study program of English Language Education at the Faculty of Tarbiyah and Teachers Training at the State Islamic University of North Sumatra Medan.

\section{Research Methods}

\subsection{Research and Research Methods}

This research carried out using a mixed method approach, which is a combination of qualitative and quantitative research. Qualitative research used is naturalistic, because it is based on the consideration that what is sought in this research is data that will describe and paint complex social reality in such a way that it becomes a concrete social phenomenon. The social situation depicted until the discovery of meaning:

1. Student response to the study program of English Language Education at the Faculty of Tarbiyah and Teacher Training in North Sumatra, Medan.

2. Expectations for the study program of English Language Education at the Faculty of Tarbiyah and Teacher Training in North Sumatra, Medan.

3. Efforts to improve quality and academic performance conducted by the study program of English Language Education at the Faculty of Tarbiyah and Teacher Training in North Sumatra, Medan.

According to Bogdan and Taylor in Moleong (1989:3) that qualitative research produces descriptions or descriptions in the form of written or oral words from the behavior of the actors that can be observed in a social situation. Furthermore, Faisal (1990: 16) argues that in studying human behavior, in-depth research is needed to the core behavior (inner behavior) holistically and departs from the perspective of the culprit.

The qualitative research activities that will be carried out have characteristics as stated by Bogdan and Biklen (1992: 23), namely:

1. Natural background as a data source.

2. The researcher is a key instrument. 
3. Qualitative research emphasizes processes rather than results.

4. Researchers with qualitative approaches tend to analyze data inductively.

5. The meaning of the actors underlying the actions of the perpetrators is an essential aspect in qualitative research.

Informants in qualitative research are purfosive samples that are intended to capture information and data from various sources and forms so that there can be specified specificities into unique contexts. Determination of informants as research samples is based on consideration of involvement in the unit of analysis.

Furthermore, the quantitative method is used to answer the third research objective, which is to reveal differences in student academic achievement from high school and aliyah madrasas. In this case, statistical tests will be carried out.

\subsection{Research Design}

The research situation chosen in this study was the academic achievement of students from high school and aliyah madrasa in the English Education Study Program at the Faculty of Tarbiyah and Teacher Training at North Sumatra State Islamic University Medan, covering a broad context, involving many actors, time different places, different processes and processes. In this social setting, later information will be found from the research subjects studied. Determination of the source of information in this study adheres to the four parameters proposed by Huberman and Miles (1992: 38), namely: context (atmosphere, situation, or setting), behavior, and events. The informant or subject of this research is directed at searching data from the elements of the Faculty Leadership, Chair of the Study Program and students of the English Language Education study program at the Faculty of Tarbiyah and Teacher Training at the State Islamic University of North Sumatra Medan. While the determination of the resource person depends on the previous elements, chosen according to the purposive rules, in this case the researcher uses special knowledge or expertise about the existing group to be chosen as research subjects representing the Faculty Leaders, Study Program Heads and students of the Faculty of Science Tarbiyah and Teacher Training of the State Islamic University of North Sumatra Medan. The main characteristics of selecting speakers are developing and sustainable, constantly adjusted and directed towards achieving data redundancy. In other words, the achievement of data will be stopped when there is no more variation of data that surfaces when researchers conduct data collection and analysis.

\subsection{Research of Procedures}

Research informants are the subjects needed to obtain information in uncovering cases that are considered. The case in this study is defined as a phenomenon that occurs at a time in the context of research that is of concern and provides important and necessary information relating to the academic achievement of students of the English Language Education Study Program at the Faculty of Tarbiyah and Teacher Training at the State Islamic University of North Sumatra Medan. Lincon and Guba (1985: 89) state: negative case analysis in qualitative research is identical to analysis of variance in quantitative research. Negative cases can be used to prove and change interpretations in the qualitative research process, to achieve saturation and credibility of research. Negative cases can facilitate the emergence of various models and explain different variations and patterns. Negative cases are needed in collecting data to provide information to readers, as a source for readers to give 
consideration to credibility theory. Consequently, in the sampling process, researchers must also consider negative cases. That means negative cases are needed in qualitative research to meet the criteria for saturation and accuracy of data collection. The extreme case is a case that is outside the case shown. The researcher also really identified cases that were in two parts as extreme cases.

In this study extreme cases are divided into two types, namely situations, something that should exist in certain situations, and informant bias, something that informants deny the truth of both are reviewed on the basis of positive and negative values. In the process of collecting and analyzing data researchers pay attention to negative and extreme cases aimed at making the evidence obtained truly reliable. The mechanism is integrated in the process of collecting data by building the credibility of the research, which began since the initial data collection, thus increasing the researchers' confidence in the data obtained.

\subsection{The Technique Data Collection}

Data collection in qualitative research uses observation techniques and in-depth interviews. Qualitative data collection using in depth interviews both structured and not structured on the actors in this case is the Faculty Leader, Chair of the Study Program and students of the English Language Education study program at the Faculty of Science Tarbiyah and Teacher Training Islamic University of North Sumatra Medan . In the beginning the data obtained from the informants were appropriate from the point of view of the informant or respondent (emic) in this case the Faculty Leader, Chair of the Study Program and students of the English Language Education study program at the Faculty of Tarbiyah and Teacher Training of North Sumatra Islamic University Medan Furthermore, the data that has been analyzed is based on the researcher's perspective (etic). Interviews with informants as resource persons for data and information were conducted with the aim of extracting information about the focus of the research. In other words, a rather more active (moderate) involvement is by trying to participate and involve and try to get closer to the informants. In other words to get to know the social situation in the background of the English Language Education study program at the Faculty of Tarbiyah and Teacher Training at the State Islamic University of North Sumatra Medan. Researchers do it by asking questions that have been structured if done formally and unstructured questions if done not formally with informants as resource persons for data and information. Furthermore, to answer the third research goal, namely differences in academic achievement between students with high school and madrasah backgrounds, the data collection technique is to look at the documentation of academic achievement that is listed in the study result card (KHS).

\subsection{The Data Analysis}

After the data and information needed are collected then analyzed in order to find the meaning of the findings. Data analysis is the process of organizing and sorting data into patterns, categories and basic description units so that themes can be found and work hypotheses can be formulated as suggested by the data. Data analysis is also intended to find elements or sections that contain smaller categories of research data. The newly acquired data consists of field notes obtained through observation, interviews and document studies in schools to be analyzed first so that they can be understood by compiling data, connecting data, reducing data, presenting data, drawing conclusions or verification during and after data collection. For that data obtained from informants then analyzed using qualitative data 
analysis interactive models of Miles and Huberman which consist of: (a) data reduction, (b) data presentation, and, (c) conclusions, where the process takes place circularly during the study take place. In the early stages of data collection, the focus of the research is still broad and not yet clear, while the observations are still general and broad. After the focus becomes clearer, the researcher uses more structured observations to get more specific data.

\subsection{Data Guarantee Techniques}

To strengthen the validity of the data of the findings and authenticity of the research, the researcher refers to the use of standards of data validity which consist of: (1) credebility, (2) transferability, (3) dependability, (4) confirmability.

\section{Conclusion}

Based on the presentation of findings and discussion as presented in the previous chapter, conclusions can be taken as follows:

1. Responses from research informants to the study program of English Language Education at the Faculty of Tarbiyah and Teacher Training at North Sumatra State Islamic University Medan from the aspect of study that was perceived to be quite different between one informant and the other informants. In this case the research findings show that in general it gives a positive response to the study program of English Language Education at the Faculty of Tarbiyah and Teacher Training at the North Sumatra State Islamic University Medan covering aspects of the learning process, curriculum, teaching staff, availability of facilities.

2. Expectations for the English Language Education Study Program at the Faculty of Tarbiyah and Teacher Training at the North Sumatra State Islamic University Medan are also seen in the element of meeting the needs of study programs towards quality study programs which are summarized into expectations: (1) uptodate curriculum, professional teaching and competency, and (3) availability of facilities that support lectures such as laboratories.

3. Efforts made by the English Language Education Study Program at the Faculty of Tarbiyah and Teacher Training at the North Sumatra State Islamic University in improving quality and academic performance related to aspects: (1) data-based program planning, (2) teaching staff recruitment, (3) information technology-based management services; and (4) graduated.

\section{References}

Hailikari T., Katajavuori, N., \& Lindblom-Ylanne, S. The Relevance Of Prior Knowledge In Learning And Instructional Design. American Association of Colleges of Pharmacy. http://www.ncbi.nlm.nih.gov/pmc/articles/PMC2630138/.2010.

Mardhiyah, Khusna, "Studi Komparasi Kualitas Pelayanan Pendidikan di Sekolah Menengah Atas Negeri 2 Rembang dan Madrasah Aliyah Negeri Rembang", Tesis pada Sekolah Pascasarjana Universitas Diponegoro, Jawa Tengah: 2012.

Nurdin, Syafruddin, Model Pembelajaran yang Memperhatikan Keragaman Individu Siswa dalam Kurikulum Berbasis Kompetensi, Ciputat: Quantum Teaching, 2005

Peraturan Menteri Riset, Teknologi, Dan Pendidikan Tinggi Republik Indonesia Nomor 44 Tahun 2015 Tentang Standar Nasional Pendidikan Tinggi. 
Siregar, Eveline dan Nara, Hartini. Teori Belajar Dan Pembelajaran. Bogor: Ghalia Indonesia, 2011

Syah, Muhibbin. Psikologi Belajar. Jakarta: Logos Wacana Ilmu, 2001.

Syah, Muhibbin. Psikologi Pendidikan Dengan Pendekatan Baru. Bandung: Remaja Rosdakarya, 2009.

Tilaar, H.A.R.. Kekuasaan Dan Pendidikan, Suatu Tinjauan Dari Perspektif Studi Kultural. Magelang: Indonesiatera, 2003. 